\title{
The Matrix Language Turnover Hypothesis: The Case of the Druze Language in Israel
}

\author{
Afifa Eve Kheir \\ The University of Adelaide \\ afifaeve.ferro@adelaide.edu.au
}

\begin{abstract}
This study examines the language of the Druze community in Israel as going through the process of convergence and a composite Matrix Language formation, resulting in a split language, a.k.a. mixed language, based on Myers-Scotton's Matrix Language turnover hypothesis (2002). Longitudinal data of Palestinian Arabic/Israeli Hebrew codeswitching from the Israeli Druze community collected in 2000 and 2017 indicate that there is a composite Matrix Language formation resulting in a split language. Such a composite involves convergence features in congruence with stage II of the hypothesis, resulting in a composite morphosyntactic frame. The main features of convergence are the introduction of Israeli Hebrew system morphemes, including early system morphemes, bridge system morphemes and outsider late system morphemes-in some cases appearing independently, but in most cases, in conjunction with content morphemes. There are features of lexical conceptual structures and morphological realization patterns as well. Sociolinguistic factors are suggested as potential motivators for such composite and split language formation.
\end{abstract}

\section{Keywords}

codeswitching - Druze - Arabic - Hebrew - matrix language

It is widely accepted by linguists that codeswitching involves the alternating use of two or more languages. However, there is a big debate regarding which type of use and to what extent can actually be referred to as codeswitching.

(C) AFIFA EVE KHEIR, 2019 | DOI:10.1163/19552629-01202008

This is an open access article distributed under the terms of the prevailing CC-BY-NC License at the time of publication. 
Myers-Scotton (1997: 3), provides a more specific definition for codeswitching in one of the models that she presented, namely the Matrix Language Frame Model, defining codeswitching as "the selection by bilinguals or multilinguals of forms from an embedded variety (or varieties) in utterances of a matrix variety during the same conversation". The Matrix Language is the main language in codeswitching production, whereas the Embedded Language plays the role of the other language participating in codeswitching, though less dominantly so. The Matrix Language sets the morphosyntactic frame of sentences showing codeswitching. It marks out the order of the morphemes and provides the syntactically relevant morphemes in constituents containing morphemes from both languages-the matrix language as well as the embedded language.

As far as codeswitching structure is concerned, it is accepted that it may be either inter-sentential or intra-sentential. Inter-sentential codeswitching involves alternating two languages between sentences, that is, producing a whole clause in one language prior to switching to the other. Intra-sentential switches occur within the same sentence or clause, with the clause containing elements of the two languages (Myers-Scotton, 1997). According to Auer and Eastman (2010), in the case of word-internal codeswitching, some scholars argue that it is not possible while others argue against this restriction. The present study, alongside many others, demonstrates that it is possible.

In the study of codeswitching, a vigorous debate exists as to whether the code-switchers; people who alternate between two (or more) languages, perceive the languages as separate from one another or as one repertoire to select from. Or as Peter Auer and Carol M. Eastman put it (2010: 86): "Are the distinctions introduced by the linguist, and held to be relevant under all circumstances (e.g. the difference between two 'languages'), relevant for the speakers, or do the speakers have their own unique perceptions and criteria for assessing what they do when speaking?"

Extensive research on codeswitching has shown that different codeswitchers within a certain community may have different switching ways and styles. This has led scholars in the field to distinguish between possible types of codeswitching. Two major approaches exist as to which contact phenomena involving surface level morphemes from more than one language should be counted as codeswitching. Hence, codeswitching is distinguished by Myers-Scotton (2002) as two main types: classic codeswitching and composite codeswitching.

In classic codeswitching, the speakers provide the morphosyntactic frame solely from one of the participating languages, namely the Matrix Language. The speakers, however, can insert content morphemes from the other participating language, that is, the Embedded Language, into mixed constituents of 
the Matrix Language or insert islands from the Embedded Language or both. In composite codeswitching, as opposed to classic codeswitching, the speakers provide the morphosyntactic frame from more than one of the participating languages, resulting in a composite Matrix Language Frame which involves convergence of the morphosyntactic frame, as well as of the features of some grammatical structures.

Such discernment between the different types of codeswitching is crucial for understanding the different motivations for codeswitching as well as its causes and effects. For further understanding and illustrations of codeswitching behaviour, different theories and models of codeswitching have been introduced, though they almost all apply to one type of codeswitching, namely classic codeswitching. When it comes to the other type, however, the literature is very limited. One of the very few linguists to propose a theory about composite codeswitching is Myers-Scotton. Myers-Scotton (1998) proposed the Matrix Language Turnover hypothesis in order to test composite codeswitching cases.

In order to test that hypothesis, longitudinal data of the relevant sort is required, therefore, very few studies were conducted to test the hypothesis. The present study attempts to test convergence and a composite Matrix Language formation resulting in a split language, a.k.a. mixed language, through a Matrix Language turnover. To test the hypothesis, the present study examines longitudinal data of Palestinian Arabic/Israeli Hebrew codeswitching, taken from the same community, namely the Israeli Druze community, and some of the same participants from the different data sets overtime (2000 and 2017). In addition, the study examines the possible factors motivating convergence and composite Matrix Language formation resulting in a split language. The phenomena of codeswitching and borrowing in Israel were studied by several researchers (Abu Elhija, 2017; Amara, 2010; 2017; Henkin, 2011; Mar'i, 2013); however, their research was aimed at different groups and localities. Isleem (2016) was among the very few researchers to study Druze codeswitching; however, his research was limited to video recordings taken from different websites and online written communication, unlike the present research which is based on actual fieldwork and longitudinal observations of naturally occurring speech.

The Druze religion is a monotheistic secretive closed religion that emerged in 1017 under the Fatimid caliphate rule in Egypt and closed its "gates" to new believers in 1043. A common belief among the Druze is that the faith existed 
much earlier than its formal revelation in 1017, which coincides with the existence of the Druze prophets dating back to Biblical times. The main and central figure of the Druze faith is the Caliph Al-Hakim bi-Amr Allah (Arabic: The ruler by command of the Deity), who is perceived by the believers as the divine manifestation of the Deity, though not the Deity itself. According to the Druze faith, God revealed himself several times in human form, with the last revelation being in the form of Al-Hakim bi-Amr Allah.

The Druze religion is secretive in the sense that its holy book-Kitab al-Hikma 'the book of wisdom', is held secret from everyone except for the highly religious Druze men and women. From a religious perspective, the Druze are divided into Suqqal/ARAB/PL (religiously) wise people (Saqel=SGM, Saqela $=\mathrm{SGF}$ ) and Juhhal/ARAB /PL '(religiously) ignorant people' (Jahel= SGM, Jahela= SGF). The Suqqal are the religious and highly revered amongst the two groups and have restricted access to the holy book. Someone who is Jahel can turn into Saqel after undergoing a series of tests and ethical requirements. The Druze people are called Al-Muwahidūn, that is, the unitarians, or those who seek oneness.They are mainly concentrated in the Middle East, especially in Lebanon, Syria and Israel, while the rest are scattered across the different continents worldwide. Their total population worldwide is less than one million.

This paper focuses on the phenomenon of composite codeswitching in the Druze community in Israel. The Druze community in Israel has a distinct speech that differs from that of the Christians and Muslims in the Arab sector. Although the Druze community shares the same first language as the Arabs in Israel, namely Palestinian Arabic, their speech is extremely unique in that it incorporates very extensive and frequent use of Israeli Hebrew. In comparison to Arabs who do not live in mixed cities with a Jewish majority, extensive codeswitching between Palestinian Arabic and Israeli Hebrew is considered the unmarked mode of communication in the case of the Israeli Druze community.

The total number of the Druze community in Israel is $139,000,{ }^{1}$ which constitutes around $1.58 \%$ of Israel's total population and $35.1 \%$ of the so called 'other' minorities in Israel. The Druze community in Israel shares many cultural similarities with the Israeli Arabs, however, as opposed to the general belief, the Druze people in Israel are not considered to be part of the Arab sector, but have their own distinct sector. There is a significant Druze population in twenty

1 Data supplied by the Israel Central Bureau of Statistics on 25.04.2017.

2 The Druze statistics are separate from the Arab sector statistics and are included under the category of 'other' religions, which include non-Arab Christians, other religions and people with no religious affiliations in the ministry of interior. 
settlements ${ }^{3}$ in Israel; thirteen of which the Druze constitute the vast majority, while in the rest they reside alongside Arab Christians and Muslims, in some as a majority while in others as a minority. There is only one village 4 in Israel in which the Druze constitute a majority while living alongside a minority of Christians and Jews.

The Druze people in Israel have intensive interaction with the Jewish people, thus experience great language contact with Israeli Hebrew speakers and their culture. Such interaction mainly takes place at work, at higher education institutions and in the military. In contrast to Arab Christians and Muslims, young Druze males are subject to the compulsory military service. Many Bedouins, however, enlist in the IDF (Israel Defense Forces) on a voluntary basis.

The Druze community has gone through a process of gaining a distinct political and national identity, one that is totally different from the Israeli Arabs. Prior to 1962, all of the communities in the Arab sector, namely the Druze, Christians and Muslims were legally counted as Arabs. In 1962, however, Israel took a major identity replacement step for the Druze, replacing their nationality from "Arab" into "Druze", both on their birth certificates as well as in their Identity Cards, while all the rest were still legally regarded as "Arabs" (Halabi, 2006). In addition to granting the Druze people an independent status as a community and a distinct political and national identity, they were also granted an independent education system; separate from the Arab one, thus encouraging the formation of a "Druze and Israeli" consciousness. According to Firro (2001), in the early 1970s efforts were made to create an "Israeli-Druze consciousness" through education, in order to counteract a process of "Arabization" among the Druze youth. This consciousness became actualized when the Druze curriculum had been completely separated from the Arab one, creating a distinctive Druze education system.

As a sign of their assimilation in Israel, most of the Druze people self-identify mainly as Israeli, or Israeli Druze. According to a research on identity affiliations of the Arabs in Israel conducted by Amara and Schnell (2004), the majority of the Druze people assign high priority to their religious identity as well as to their citizenship in Israel. According to Nisan (2010:576), "for the Druze, the Israeli identity, not just the formal citizenship, is a special communal badge that indicates that Israeli-ness sustains not only Jews but non-Jews as well."

3 The thirteen settlements with the vast majority of Druze are: Daliat El-Carmel, Julis, Yarka, Sajur, 'Ein El-Asad, Beit Jann, Jath-Yanuh, Kisra-Smei', Hurfeish, Majdal Shams, Buq'ata, Mas'ada and 'Ein Qinya. The rest are Mghar, Peqi'in, Shefar'am, Kfar Yassif, Abu Snan and Rama.

4 Osfiya is the village in which the Druze live alongside Christians and Jews. 
Palestinian Vernacular Arabic (henceforth PVA) is a subgroup of Levantine Arabic. It belongs to the Semitic language family and is influenced by different Middle Eastern languages, both ancient and modern, such as Aramaic, Canaanite, Ottoman Turkish, Standard Arabic and Hebrew. Its vocabulary is also influenced by European languages, such as Latin, Greek, French, Spanish and English. It is the mother tongue of Israeli Arabs and Druze and is used as a third language by some Israeli Jews. Arabic is also the mother tongue of some Jews who have migrated to Israel from different Arab countries. Within the native Arabic speaking community in Israel, Arabic is used in all domains of life. According to Amara (2017), the Arabic dialect of the West Bank is very similar to the Arabic dialect spoken in Israel. The differences between the two stem from contact with Hebrew. While native Arabic speakers in Israel start learning Hebrew at a young age and come in contact with Hebrew native speakers in various domains of life, such contact is very limited in the West Bank.

Israeli Hebrew (henceforth $I H$ ) is a multifaceted Semito-European hybrid language whose grammar is based mainly on Hebrew, and to some extent on Yiddish, Polish, Russian and PVA. The phonetics and phonology of Israeli Hebrew are European, primarily Yiddish. Israeli emerged in Eretz Yisrael 'land of Israel' (which at the time was known as Palestine) in the late nineteenth and early twentieth century. Israeli citizens speak it to varying degrees of fluency. It is used as a first language by most Israeli Jews, as well as by some Israeli Druze and Arabs who are born and raised in Jewish cities. It is used as a second language by Druze, Muslims, Christians and others in Israel. It is also used by some non-Israeli Palestinians, as well as Diaspora Jews. During the past century, Israeli has emerged as the official language in Israel, as well as "the primary mode of communication in all domains of public and private life among Israeli Jews" (Zuckermann, 2006, 2008, 2009: 41, 2010).

Coming from the same language family (West Semitic), PVA and IH share many linguistic similarities, however, they are not mutually intelligible and as such, there are many differences between them. Since the present study focuses solely on the spoken varieties of Arabic and Hebrew in Israel, I briefly outline some of the similarities and differences between those specific varieties.

Articles: Both PVA and IH have definite articles, but no indefinite articles. In Arabic, the definite article is either al- or $e l-$, and in Hebrew, it is $h a-$. In both languages, the definite articles are clitics prefixed to nouns and adjectives. However, in contrast to Hebrew in which the article has consistent pronunciation, the $l$ in the Arabic article maintains its original pronunciation, unless it is prefixed to a word beginning with a sun letter $(\mathrm{t}, \mathrm{t}, \mathrm{d}, \underline{\mathrm{d}}, \mathrm{r}, \mathrm{z}, \mathrm{s}, \breve{\mathrm{s}}, \mathrm{s}, \mathrm{d}, \mathrm{t}, \mathrm{z}, \mathrm{l}, \mathrm{n})$, 
with which it assimilates. For example: $\boldsymbol{e d}$-dahab/ARAв, ha-zahav/НEв 'the gold'; ett-tawle/ARAB, ha-šolxan/H В 'the table'; el-walad/ARAB, ha-yeled/HEB 'the boy'

Nouns: Most nouns in Arabic and Hebrew are made of lexical roots. Such roots are put into affix templates to form meaningful nouns. Nouns in Arabic and Hebrew show number and gender (see below, Agreement). Arabic nominals include singular, dual and plural features whereas Hebrew generally uses only singular and plural. As for the gender feature, Arabic and Hebrew have two types of markers: masculine and feminine. The neuter marker is not morphologically encoded in either of them.

Pronouns: pronouns have similar case features in both languages, and they inflect for person, gender and number. Shared cases include: nomina-

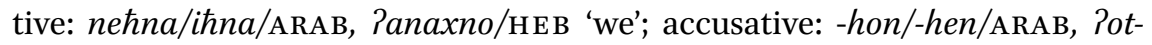

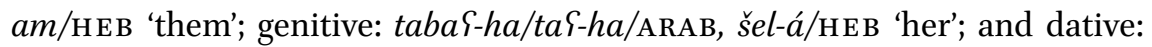
il-na/ARAB, la-nú/HE B 'to us'.

Adjectives: In both languages, adjectives agree in gender, number and definiteness with the modified nouns (see below, Agreement). In the comparative construction, however, Arabic conforms to the $\mathrm{aC}_{1} \mathrm{C}_{2} \mathrm{a}\left(\mathrm{C}_{3}\right)$ pattern of the masculine singular form across all genders and numbers to form the comparative, whereas Hebrew uses the adjective with either the word yoter 'more', or paxot

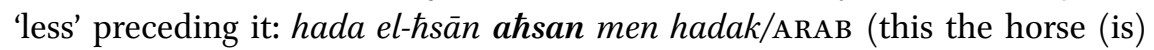
better than that), ha-sús haze yoter tov me-ha-šeni/НЕв (the horse this (is) more good than the second) 'this horse is better than that one'. In the superlative form, Arabic uses the same form as in the comparative, whereas Hebrew uses the adjective with the word haxi 'the most' preceding it: häi ahsan sayyara/ARAB (this better car), ze ha-?auto haxitov/HEB (this the car the most good) 'this is the best car'.

Verbs: In the two languages, verbs have either three or four consonants in their simple form, which is called zader/ARAB, šoreš/HE B 'root'. The two languages have three tenses: present, past and future (see below, Verbal Sentences). Verbal forms in both languages inflect for person, gender, number and tense. However, unlike Arabic, Hebrew verbs in the present tense inflect only for gender and number, and there is no person distinction (cf. Zuckermann, 2006). In addition to the three tenses, verbs in both languages are conjugated according to person, gender and number in the imperative mood: $i$-ftah el-bāb/2SGM, i-ftah-i (e)l-bāb/2SGF, i-ftah-ō (e)l-bāb/2PL/ARAB; ti-ftax et ha-delet/2SGM, ti-ftix-i et ha-delet/2SGF, ti-ftix-ú et ha-delet/2PL/HEв 'open the door!'

Clitics: In addition to the definite articles, Arabic and Hebrew have other shared clitics. For instance, some of the prepositions act as proclitics in both languages: $\{a-/ \mathrm{ARAB}, l e-/ \mathrm{HEB}$ 'to' $\{a$-lquds/АRАВ, le-yerušalayim/Нев 'to 
Jerusalem'; be-/fe-/ARAB, ba-/HEB 'in' be-lbeit/fe-lbeit-/ARAB, ba-bayet/HE B 'in the house'; la-/АRAB, le-/HEB 'for' fi maktub la-SAnan /ARAB, yeš mextav leSAnan /Hев (there (a) letter for Anan) 'there is a letter for Anan'. Possessive adjectives in Arabic are attached as enclitics to nouns. Although Standard Hebrew exhibits such enclitics, they are much less frequent in the spoken variety. Instead, the 'of' form (taba'/ARAB shel/HEB=of), which agrees in gender and number with the noun it describes in both Arabic and Hebrew, is more commonly used in spoken Hebrew: ktāb-i/ARAB, sefr-i/HEB (book my) 'my book'; el-ktäb taba -i/ARAB, ha-sefer šel-i/HЕ В (the book of me) 'my book'; sayyaretha/ARAB (car her), ha-auto šel-a /HEB (the car of her) 'her car'. Similarly, the Arabic possessive pronouns are attached as enclitics to the word Send 'at/to', to express the verb 'to have', whereas Hebrew uses yeš (there is) before the possessive pronouns, which are also attached to the preposition l'to': Yend-ha beit kbir/ARAB (at her (a) house big), yeš l-a bayet gadol/HEB (there is to her (a) house big) 'she has a big house.' While Arabic uses direct and indirect pronominal objects as enclitics, such a form is rare in Hebrew: axadt-o /ARAB, lakax-ti Poto/HEB '(I) took him'; Smelt-tel-o akel/ARAB, hexant-i lo ?oxel/H EB ((I) made for him food) 'I prepared him food'.

Word order: Although the main word order in Arabic is vso and in Hebrew is svo, it is inconstant and changeable in the spoken varieties. akal-et toffaha/ARAB, axal-ti tapuax/HEв (ate I (an) apple) 'I ate an apple', ?ana ba-Sallem tollāb/ARAB, Pani melam-éd stodent-im/H EB 'I teach students'.

Agreement: Arabic and Hebrew are languages with a rich agreement system. Agreement in Arabic and Hebrew usually involves the person, gender, number and definiteness features. Both Arabic and Hebrew exhibit two gender markers: masculine and feminine. Although both languages do not exhibit gender constraints, in most cases the suffixes $-e$ or $-a$ in Arabic and $-a$ or $-t$ in Hebrew indicate the feminine form: $m$ Sallem $/ \mathrm{M}, m$ Salm-e/F/ARAB; mor-e/M, mor- $a / \mathrm{F} /$ H E B 'teacher'. Number markers in Arabic include singular, plural and dual, whereas in Hebrew the dual form is very rarely used. Generally, the suffixes -in/ARAB and -im/HEB, as well as the infix $\langle\bar{a}>/ \mathrm{ARAB}$ are used for the masculine plural form; $-\bar{a} t / \mathrm{ARAB}$ and $-o t / \mathrm{HEB}$ are used for the feminie plural form: $m$ ialm-in/M, mialm-ät/F/ARAB; mor-im/M, mor-ót/F/HEB 'teachers'. Unlike Hebrew, Arabic exhibits many other plural patterns in the broken plural form, i.e. the irregular form, which are usually formed by changing the pattern of the consonants and vowels of the singular noun. The Arabic dual form is expressed in the suffix -ēn: binet, bint-ēn, ban-ät/ARAB '(a) girl, two girls, girls'; yald-a, yelad-ót/Н Е В '(a) girl, girls'. The agreement features hold between subjects and verbs as well as nouns and adjectives: akal-et el-binet toffa (ate the girl (an) apple) 'the girl ate an apple', akal-o el-wl $<\overline{\boldsymbol{a}}>d$ toffah/АRAB 
(ate the boys apples) 'the boys ate apples'; ha-yald-a axl-a tapuax/Hев 'the girl ate (an) apple', ha-yelad-im axl-ú tapux-im/Hе в 'the boys ate apples'. Although noun-adjective agreement in both languages involves definiteness, the definite article does not change and has a consistent form across all genders and numbers: $\boldsymbol{e l - b i n e t}$ el-helw-e/ARAB; $\boldsymbol{h a - y a l d - a}$ ha-yaf-a /HEB (the girl the beautiful) 'the beautiful girl', el-ban-ät el-ћelw-ät/ARAB; ha-ban-ót ha-yaf-ót /НEB (the girls the beautiful) 'the beautiful girls'.

Pro-drop: Arabic and Hebrew are considered pro-drop languages; hence allow the ellipsis of subject pronouns, except for the Hebrew present tense. The agreement elements (person, number and gender) within the verb conjugations make it possible to fully identify the empty category of the subject: baћeb-ha/ARAB '(I) love her', ani Pohev Pota/HЕв (I love her) 'I love her'; katab-It maktub/ARAB, katav-ti mextav/HE B (wrote (I) (a) letter) 'I wrote a letter'.

Nominal sentences: Arabic and Hebrew share many basic sentence structures. In present tense sentences (affirmative and negative), for instance, both Arabic and Hebrew generally have the subject linked with a predicate without using a copula, thus forming nominal sentences, often referred to as equational sentences. For example:

1) hada ktäb/ARAB, ze sefer/HEB

DEM N/ARAB, DEM N/HEB

this (a) book, this (a) book 'this is a book'

hada miš ktāb/ARAB, ze lo sefer/HEB

DEM NEG N/ARAB, DEM NEG N/HEB

this not (a) book, this not (a) book 'this is not a book'

Similarly, in both languages, interrogative sentences are formed by changing the intonation and tone of the voice: hada ktäb?/ARAB, ze sefer?/HEB (this (a) book?) 'Is this a book?'; hada miš ktāb?/ARAB, ze lo sefer? /HEB (this not (a) book?) 'Isn't this a book?'

Copular sentences: Arabic and Hebrew share the copular sentence structure in which the copulas, when used, agree with the subject in person, gender and number: Sammy bicun Samm-i/ARAB, Sammy húdod šeli/HE B (Sammy is uncle mine) 'Sammy is my uncle'; Einav bitcun mialmet-na/ARAB, Einav hi mora šel-ánu/Hев (Einav is teacher ours) 'Einav is our teacher'. Although Hebrew sometimes maintains the copula in the negative form with the addition of the Hebrew negation marker lo 'no/not', Arabic omits the copula and only uses the negation marker miš 'not': Sammy miš famm-i/ARAB (Sammy not uncle 
mine), Sammy húlo dod šeli/HE B (Sammy is not uncle mine) 'Sammy is not my uncle'); Einav miš mialmet-na/ARAB (Einav not teacher ours), Einav hi lo mora šel-ánu/HEB (Einav is not teacher ours) 'Einav is not our teacher'.

Verbal sentences, Verbal present tense sentences (I): Both Arabic and Hebrew have an equivalent to the English Present Simple tense. In Arabic, the verbs are conjugated according to the person, gender and number of the subject, whereas in Hebrew they are conjugated only according to gender and number (Zuckermann, 2006): ?ana bakt-ob/bakt-eb/ARAB, ?ani kot-ev/HEB 'I

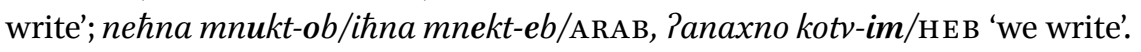

While Hebrew only adds a time expression to the above form to indicate the Present Continuous tense, Arabic attaches the prefix Sam- to express such a form: ?ana \{am-bakt-ob/\{am-bakt-eb issa/ARAB, ?ani kot-ev \{axšav/HE B 'I (am)

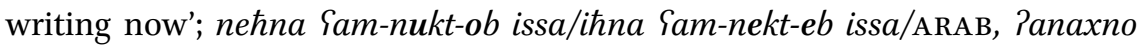
kotv-im Saxšav/HEB 'we (are) writing now'.

Verbal Past tense sentences (II): Both Arabic and Hebrew have an equivalent to the English Past Simple tense. In the Past Simple, the verbs are conjugated according to the person, gender and number of the subject, in both Ara-

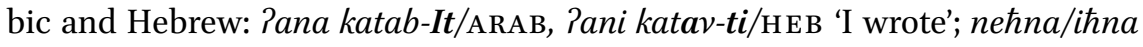
katab-na/ARAB, ?anaxno katav-nú/H EB 'we wrote'. The Past Continuous tense, although common in Arabic, is generally not used in Hebrew. The Past Continuous in Arabic is formed by using the copula kan 'was' before the present progressive form. The Arabic copula kan agrees with the subject in person, gender and number: ?ana kun-et Sam-bakt-ob/Sam-bakt-eb/ARAB 'I was writing'; neћna kun-na Sam-nukt-ob/itna kun-na Sam-nekt-eb/ARAB 'We were writing'.

Verbal Future tense sentences (III): In both Arabic and Hebrew future tense ('will form'), the verbs are conjugated according to the person, gender and number of the subject. In addition to the verb conjugation, Arabic requires an auxiliary before the verb for both the 'will' and 'going to' forms, whereas Hebrew only requires one for the 'going to' form. As opposed to Arabic, Hebrew uses the infinitive verb for the 'going to' form, which does not change for person, gender or number. The auxiliaries used for the 'going to' form are $r a \hbar / A R A B$ and holex le-/HEB 'going to'. In addition to the auxiliary rah/ARAB, the word bad-i (want) 'will', is also used for the 'will' form and is usually shortened in the 1PL from bad-na into $n a$ - (we want) 'we will'. The auxiliary rah/ARAB 'going to' does not change for person, gender or number unlike all the rest, but its following verb does: ?ana rah akt-ob/akt-eb/ARAB, ?ani holex le-xtov/HE ' I (am) going

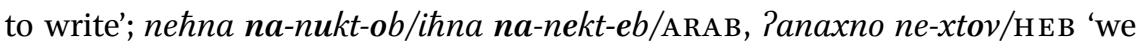
will write'; hunne rahyu-kutb-ü/henne rahye-ketb-ü/ARAB, hemye-xtev-ú/HEB 'they will write'. 
In this study, the language of the Druze community shall be examined as going through the process of convergence and a composite Matrix Language formation, resulting in a split language, based on Myers Scotton's matrix language turnover hypothesis, which necessarily involves composite codeswitching. According to Myers-Scotton (2002), the matrix language turnover hypothesis requires longitudinal data of the relevant sort in order for it to be tested. The present study is based on data sets that were compiled in 2000 as well as 2017. Convergence is defined by Myers-Scotton (2006: 271) as "speech by bilinguals that has all the surface level forms from one language, but with part of the abstract lexical structure that underlies the surface-level patterns coming from another language (or languages)." Convergence occurs when there is a Matrix Language turnover in codeswitching. In between convergence and a complete turnover of the Matrix Language, there lies a stage of a composite Matrix Language formation. Composite Matrix Language formation occurs in a process called composite codeswitching. According to Fuller (1996), the defining feature of a converging language is the presence of this composite Matrix Language, which constitutes the second phase of a Matrix Language turnover.

Composite codeswitching is defined by Myers Scotton (2006: 242) as "a bilingual speech in which even though most of the morphosyntactic structure comes from one of the participating languages, the other language contributes some of the abstract structure underlying surface forms in the clause." According to Myers-Scotton's Matrix Language Frame model (2006), in classic codeswitching, only one of the languages participating in the switch provides the morphosyntactic frame; namely the Matrix Language. In composite codeswitching, however, the morphosyntactic frame is provided from more than one of the participating languages, resulting in a composite Matrix Language frame, which involves convergence of the morphosyntactic frame, as well as of the features of some grammatical structures. Myers-Scotton (2002: 9) states that according to the Asymmetry Principle even if the Matrix Language involves a composite of abstract features from more than one language, "asymmetry still marks the contributory roles of the participating languages" and there is always "a movement toward the morphosyntactic dominance of one variety in the frame." Myers-Scotton (2002) defines split languages as languages that are based on input from two other varieties, showing a split in their basic organization. Such split either occurs in the lexicon and the grammatical system, or within the grammatical system and some types of morphology and phrase structures. According to the Matrix Language 
turnover hypothesis, split languages arise when there is a matrix language turnover underway, but it does not reach full completion.

\subsection{The Matrix Language frame model and the 4-M model}

According to Myers-Scotton (2002: 247), "the Matrix Language is a theoretical construct, encapsulating the notion that all CPs (Projection of Complementizer) in any language are structured at the abstract level by a morphosyntactic frame." Such a frame is defined as the Matrix Language. In classic codeswitching, the Matrix Language is the one providing the morphosyntactic frame under the Matrix Language Frame model. In the "classic" Matrix Language Frame model, further discussed in the 4-M model of Myers-Scotton and Jake (2001), four types of morphemes are classified: (1) content morphemes and (2) system morphemes that are subdivided into early system morphemes and two types of late system morphemes: (3) bridge late system morphemes and (4) outsider late system morphemes.

Content morphemes are morphemes that assign or receive thematic roles (theta roles). Given that verbs usually assign theta roles and nouns usually receive them, they are prototypical examples of content morphemes. According to the Matrix Language frame model, such morphemes frequently come from the embedded language. Early system morphemes, on the other hand, are morphemes that depend on their head for further information, yet they do not assign or receive theta roles. Such morphemes include plural markings, determiners, and some prepositions called satellites that affect the meanings of some phrasal verbs in English. In Arabic and Hebrew examples of such morphemes include demonstratives that show agreement with their heads in both gender and number, such as (hai/ARAB hazot/HEB=this/sGF). Bridge late system morphemes are morphemes that occur between phrases to produce a larger constituent. Examples of such morphemes include the possessive elements, such as of and the possessive marker $-s$ in English. In Arabic and Hebrew respectively, the possessive elements that show agreement in both gender and number, as well as the possessive suffixes in Arabic, are examples of such morphemes (taba'/ARAB shel/H EB $=\mathrm{of})$. Outsider late system morphemes are morphemes which depend on information that is outside the element with which they occur. According to Myers-Scotton and Jake (2017), they are the agreement elements that make more transparent relationships between elements in the clause, especially in their roles as case markers or in co-indexing relations between arguments and verbs. For instance, the form of the agreement marker in subject-verb agreement in English depends on the subject, so whenever there is a third-person singular in the present tense, the suffix $-s$ occurs, otherwise, it does not. 
Similarly, Arabic and Hebrew subject-verb agreement is expressed through the addition of different clitics, depending on the tense, gender and number and cannot occur otherwise. Quantifiers in Arabic and Hebrew, such as $\mathrm{kull} / \mathrm{ARAB}$ and $\mathrm{Kol} / \mathrm{HEB}$ 'all' "look" outside their maximal projection when they are added to clitics to show gender and number agreement as in kull-hun/kullayat-(h)un/ARAB/PL and kol-am/HEB/M/PL 'all of them'. Also, in both Arabic and Hebrew the object pronouns change depending on case markers and the type of verb that requires them, for instance in hiye naqalIt-ni/ARAB, hi he'vir-a ?oti/HEB 'she moved me', both the Arabic suffix -ni and the Hebrew object pronoun ?oti appear as the accusative case of 'me'. Whereas in hiyye šarahItli ed-dars/ARAB, hi hesbir-a li et ha-še'úr/HE B 'she explained to me the lesson' both the Arabic suffix -li and the Hebrew object pronoun li appear as the dative case of 'me'. According to Myers-Scotton (2002: 248) "the late system morphemes are of special interest because they are structurally assigned, called by the grammar rather than accessed to convey speaker intentions." Myers-Scotton (1993) also asserts that in classic codeswitching, the system morphemes coming from the Embedded Language must come in the form of embedded language islands. Such islands include: formulaic expressions and idioms, other time and manner expressions, quantifier expressions, non-quantifier, non-time NPS as VP complements, agent NPS and thematic role and case assigners. Myers-Scotton (2008, 2013), Jake and Myers-Scotton (2009) and MyersScotton and Jake $(2009,2017)$ further emphasize that in classic codeswitching, bridges and outsiders are never provided by the Embedded Language Furthermore, in composite codeswitching, embedded language outsiders do not occur, except in the form of islands, which is also not very common.

Out of the category of system morphemes, one type of system morphemes, namely the outsider late system morpheme, plays a critical role in defining the Matrix Language as is evident in Myers-Scotton's System Morpheme Principle (2002: 59): "in Matrix Language + Embedded Language constituents, all system morphemes which have grammatical relations external to their head constituent (i.e. which participate in the sentence's thematic role grid) will come from the Matrix Language."

According to Myers-Scotton (2002: 248), the outsider late system morphemes are of utmost importance, and when they are provided from the "previous" Embedded language, that is a sign that there is an evident change in the morphosyntactic frame structuring the language. Convergence, which involves the splitting and recombining of abstract grammatical structure, causes the frame to change and receive system morphemes from the second language. Therefore, "a chain of events, beginning with convergence, results in new grammatical outcomes on both abstract and surface levels." 
This study examines convergence and a composite Matrix Language formation resulting in a split language, mainly based on system morpheme occurrences. Since both Arabic and Hebrew are Semitic languages that share many similarities in morpheme order, the Morpheme Order Principle ${ }^{5}$ is sparsely utilized in this study.

\subsection{The Matrix Language Turnover hypothesis}

In opposition to the Matrix Langauge Frame model in which only one language provides the morphosyntactic frame, the Matrix Language turnover hypothesis suggests that there is a phase in which the Matrix Language becomes a composite, that is, both languages make up the morphosyntactic frame. Myers-Scotton $(1998,2002,2003)$ and Fuller (1996) further explicate the stages of the Matrix Language turnover hypothesis:

Stage I: In this stage, intra-sentential codeswitching occurs frequently, though the Matrix Language is still the provider of the system morphemes and sets the morphosyntactic frame by itself. As in the "classic" Matrix Language Frame model, the Embedded Language contributes the content morphemes as well as the Embedded Language islands to the Matrix Language Frame. Borrowings from the Embedded Language become core borrowings, and EL structures may become lexicalized in the Matrix Language. Some of the Matrix Language categories may take on the functions of the Embedded Language.

Stage II: In this stage, composite codeswitching occurs, as both languages begin to converge, causing the previous Matrix Language to lose its undisputed role as the source of the Matrix Langauge Frame in bilingual CPs. Simultaneously, the embedded language gains power. Convergence is represented by the splitting and recombining of abstract lexical structure, having both the Matrix Language and the Embedded Language set the morphosyntactic frame, altogether forming a composite Matrix Language. There are three types of convergence that occur throughout the process of the composite Matrix Language formation:

(1) The 'previous' Embedded Language provides late system morphemes, mainly with content morphemes from the same language. In comparison, bridge and outsider late system morphemes are strictly provided by the Matrix Language, in the case of classic codeswitching;

5 The Morpheme Order Principle of Myers-Scotton (2002: 59): "in Matrix Language + Embedded Language constituents consisting of singly occurring Embedded Language lexemes and any number of Matrix Language morphemes, surface morpheme order (reflecting surface syntactic relations) will be that of the Matrix Language." 
(2) A violation of congruence requirements occurs, since both the Matrix language and the Embedded Language provide lexical conceptual structures and morphological realization patterns. Such structures will come out from either or both of the languages, forming a composite language structure;

(3) If the Matrix Language has a diversity of structures, such as word order possibilities, then the preferred structure would be that most resembling the Embedded Language construction.

Stage III: In this stage, there is a complete turnover of the Matrix Language. Such turnover is characterised by a turnover of the System Morpheme Principle. While in the Matrix Language Frame model the Matrix Language was the main contributor of the system morphemes occurring with content morphemes from the Embedded Language; here it is the complete opposite: The previous Embedded Language, which becomes the new Matrix Language, provides the system morphemes, with the occurrence of content morphemes from the former Matrix Language, i.e. the new Embedded Language. Content morphemes may also come from both languages, though with the new Matrix Language lexical-conceptual and predicate-argument structures.

Myers-Scotton (2002: 249) argues that "split languages represent turnovers that do not go to completion, but stop 'along the way'; where they stop partly determines the form they show today." The main analysis of the data of this study assesses the language spoken by the Druze community in Israel as a composite Matrix Language resulting in a split language, that is, one that is constructed from linguistic varieties of two languages: Palestinian Arabic and Israeli Hebrew. Therefore, the second phase of the Matrix Language Turnover hypothesis is of utmost relevance to the current study.

\section{5}

\section{Split languages}

Many researchers proposed different definitions as to what counts as a split language, a.k.a. mixed language. Most of the definitions include lists of lexical and grammatical elements. However, Myers-Scotton (2002: 249) contrasts such definitions and proposes two definitions, one strong definition and a less stringent one respectively:

I-A split language exhibits almost its entire morphosyntactic frame from a different source language from large portions of its lexicon; this frame includes almost all of its late system morphemes from the language of the morphosyntactic frame. 
II-A split language exhibits a major constituent with its system morphemes and major parts of the morphosyntactic frame from a different source language from that of most of the lexicon and the morphosyntactic frame of other constituents.

Myers-Scotton explains that the overall difference between split languages and other languages lies in the sense that the splits occur not only in features, but also in systems of features. In the case of system morphemes, for instance, they count as a system, whereas late system morphemes count as a subsystem, hence a system of a feature.

When differentiating between a composite Matrix Language that is characterized as such for its composite abstract structure and a split language, she suggests two abstract constructs (2002: 252): (1) the notion of a composite Matrix Language that includes both abstract lexical structure and a split of the source for grammatically crucial surface-level system morphemes and the main source for content morphemes, and (2) the notion that this state of affairs begins a Matrix Language turnover, but a turnover that is arrested at some point.

Under such definitions, Myers-Scotton recognizes three languages that count as split languages: I-Michif, a unique mixed language which is composed of a mixture of Cree and French, and is spoken by fewer than a thousand people in the provinces of Saskatchewan and Manitoba in Canada, and in North Dakota and Montana in the United States (Bakker, 1997). II-Ma'a, a.k.a. Mbugu, a split language that is spoken in the Usambara district of north-eastern Tanzania. Its structure mainly consists of a Bantu grammar (Pare and Shamba) and a Cushitic lexicon (Mous, 2003). III-Mednyj Aleut, which is a split language of the Copper Island Aleuts (CIA) (Vakhtin, 1998). According to Thomason (1997), this language was moribund and was rapidly replaced by Russian. It is composed of Aleut lexicon and Russian grammar.

Such split languages, among the rest, generally come from the same sociolinguistic background. According to Bakker (1997: 203), these languages "are spoken by ethnic groups who were originally bilingual but, for some reason, wanted to distinguish themselves collectively from both groups whose languages they speak. The speakers of each of these languages form a distinct group, either a subgroup of a larger division or a completely different group." Such split language formation stresses the distinctness of the group. Split languages have special names which distinguish them from other languages spoken in the area which consequently form a distinct identity of the speakers of such language. In the case of the Druze community in Israel that is "sandwiched" between the Arabs and Jews, forming a new split language denotes a distinct group, which is distinguished from both groups "whose languages they speak." 


\section{Data and Examples}

\subsection{The data collection}

The data used in this study is based on different data sets from the years 2000 and 2017. All data come from recordings of spontaneous speech, that is, naturally occurring conversations. All the examples involving Hebrew/Arabic codeswitching were audio-recorded in different places in Israel. The fieldwork generated seventeen recordings. Each recording lasted around 6o minutes, and speakers were involved in codeswitching for most of the recordings.

The participants of the present study are ten Druze speakers, 6 females and 4 males, coming from different Druze villages (excluding the Golan Heights) and Arab/Druze mixed villages in Israel, and their language behaviour reflects the language behaviour of the majority of the other residents in their villages. Six recordings include the same participants from the previous data set (2000). All participants are multilingual speakers, highly proficient in both Arabic and Hebrew, with Arabic occupying their L1 and Hebrew their L2. They range in age from 25 to 45 . The speakers include 5 professionals (a TV journalist, a teacher, a shopkeeper, a manager and a customer service agent) and 5 students from different departments, at various degree levels. Switching between these languages is extremely common among the Druze community, and almost in all the Druze villages in Israel, it is considered the unmarked mode of communication.

TABLE 1 Distribution of the Participants by gender, age, occupation and year/years of participation

\section{Participant Age Gender Occupation Data set 2000 Data set 2017}

\begin{tabular}{rlllll}
\hline 1 & 25 & F & Student & + \\
2 & 35 & F & Student & + \\
3 & 45 & F & Shopkeeper & + & + \\
4 & 39 & M & Customer service agent & + & + \\
5 & 36 & F & Student & + & + \\
6 & 44 & M & Manager & + & + \\
7 & 42 & M & Teacher & + & + \\
8 & 35 & M & Student & & + \\
9 & 33 & F & Student & & + \\
10 & 38 & F & T.V. Journalist & + & + \\
\hline
\end{tabular}




\subsection{Examples and analysis}

To illustrate the process of convergence and a composite Matrix Language formation through a Matrix Language turnover in the given community, I present tables with data from the different years and analyse different examples of codeswitching between the two languages. The research questions addressed for the following examples are: Is there any difference between the types of codeswitching used in the different data sets? Is there a case of a turnover of the Matrix Language? Is there a case of a split language formation?

The main premises to be supported, especially for these data, are the following: First, codeswitching among the Israeli Druze has been changing over the years from classic codeswitching to composite codeswitching. Second, the turnover does not go to full completion but stops along the way, forming a new split language. Table 2 shows the total number of the sampled CPs, ${ }^{6}$ as well as morphemes coming from both languages recorded in the previous data sets (2000).

\subsubsection{Examples of codeswitching}

Examples (2) through (7) illustrate Arabic/Hebrew codeswitching from the previous data sets (2000). All examples are of multilingual speakers fluent in both Palestinian Arabic and Israeli Hebrew, with Palestinian Arabic being their

TABLE 2 Proportion of the languages in codeswitching (2000)

\begin{tabular}{llll}
\hline Language & Palestinian Arabic & Israeli Hebrew & Both Languages \\
\hline $\begin{array}{l}\text { Total number of CPS } \\
\begin{array}{l}\text { Total number of } \\
\text { morphemes }\end{array}\end{array}$ & 817 & 698 & 602 \\
\begin{tabular}{l} 
Percentage \\
\hline
\end{tabular} & $53.9 \%$ & $46.1 \%$ & 1515 \\
\hline
\end{tabular}

6 Myers-Scotton (2010) chooses the CP (projection of complementizer, i.e. a clause with a complementizer, where the complementizer is often null) as a unit of analysis for the following reasons: (i) A CP is the highest unit projected by lexical elements and can be defined in terms of phrase structure. (ii) It is used as a unit of analysis for different syntactic models. (iii) A CP can contain null elements, thus avoids problems regarding the status of constituents with null elements such as exclamations. 
native tongue. In classic codeswitching, the Matrix Language sets the morphosyntactic frame. Embedded Language lexemes, however, are either integrated into the Matrix Language Frame; appear in bare form, or as part of an Embedded Language island. In the Arabic/Hebrew codeswitching data recorded in 2000, such constraints are realized. In (2) there is an instance of a common switch in which the definite article in Palestinian Arabic el- or al- 'the', which is not a free morpheme but is prefixed to nouns and adjectives in Arabic, is actually prefixed to nouns in Hebrew, thus Hebrew nouns are inserted into an Arabic frame. Hebrew-derived elements are underlined; other elements are from Arabic, morphemes under discussion or focal are in bold.

$\begin{array}{llllll}\text { (2) } \breve{s} \bar{u} & \text { kanet el-ta̧ana innu lamma dašar-u } & \text { awal marra? } \\ \text { What was the-claim that when split-PST-3PL first time? }\end{array}$

'What was the claim when they split the first time?'

In (3) a young Druze lady produces a Hebrew masculine noun inflected with the Arabic feminine plural suffix - $\bar{a} t$, which is usually suffixed to the feminine singular stem of the nouns in Arabic, thus forming a hybrid plural. In Hebrew, the plural suffix-im is added to the masculine singularnouns, thus the word $p k a k$-im '(traffic) jams' would be the standard. It is important to note that the word $p k a k$ '(traffic) jam' is a case of a core borrowing, since Arabic has the viable equiva-

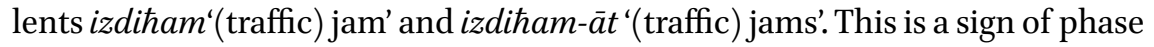
I of a Matrix Language turnover since the core borrowing of the Hebrew word pkak has its structure becoming lexicalized in the Matrix Language, Arabic, as it is given plural according to the Arabic pattern. Matras (2009) suggests viewing the phenomena of borrowing and codeswitching as related points on a continuum. According to his theory, the word $p k a k$, for instance, would have started at one point and moved to the other end of the codeswitching-borrowing continuum.

(3) Slixa inno tiakhar-et heik pašüt kan fi ktir pkak-ät Sa-tariq Sorry that be late-1SG-PST like that simply was in a lot traffic-PL on-the way 'Sorry that I was late, there was simply a lot of traffic on the way.'

In (4) a Druze male uses an Arabic auxiliary for a verb in the future in Hebrew, in which auxiliaries are not commonly used in such a case, instead, the verb itself is inflected for the future tense. In Hebrew the sentence would be: 'ani $i$-stader eito, al tid?ag-i' 

(4) ana rah a-stad-er mas-o al tidiag-i
I will 1SG-FUT-get/along with-him not worry-2SG-PRS
'I will get along with him, do not worry.'

Example (5) shows a Hebrew verb which is inflected with an Arabic pronominal clitic and followed by an Arabic direct object. In Arabic $a$ - is prefixed to the verb after an auxiliary to mark the future tense, whereas in Hebrew le is prefixed to the verb in such cases.
(5) ana rah a-nak-e el-beit issa
I going to 1SG-clean-FUT the-house now
'I am going to clean the house now'

In Arabic, the sentence would be:

'ana rah a-nadef el-beit issa'

I going to 1SG-clean-FUT the-house now 'I am going to clean the house now'

And in Hebrew, the equivalent would be:

'ani holex-et le-nakot et ha-bayet 'axshav'

I going to-1SGF INF-clean the-house now 'I am going to clean the house now'

Example (6) shows codeswitching that is reflected in change in word order. In the example below, a Druze lady switches the word order of the Hebrew determiner ka-zot and the noun semla to match it to the order in Arabic. In Arabic it would be heik festyan (such (a) dress), whereas in Israeli Hebrew it would be semla ka-zot ((a) dress such) 'such a dress'. In addition, the speaker uses an Arabic copula kon-et 'was' with a Hebrew adjective mogb-elet 'limited' which shows agreement with the Arabic pronoun 1SGF. This example illustrates the role of Arabic as the Matrix Language, since it sets the morpheme order of the frame.

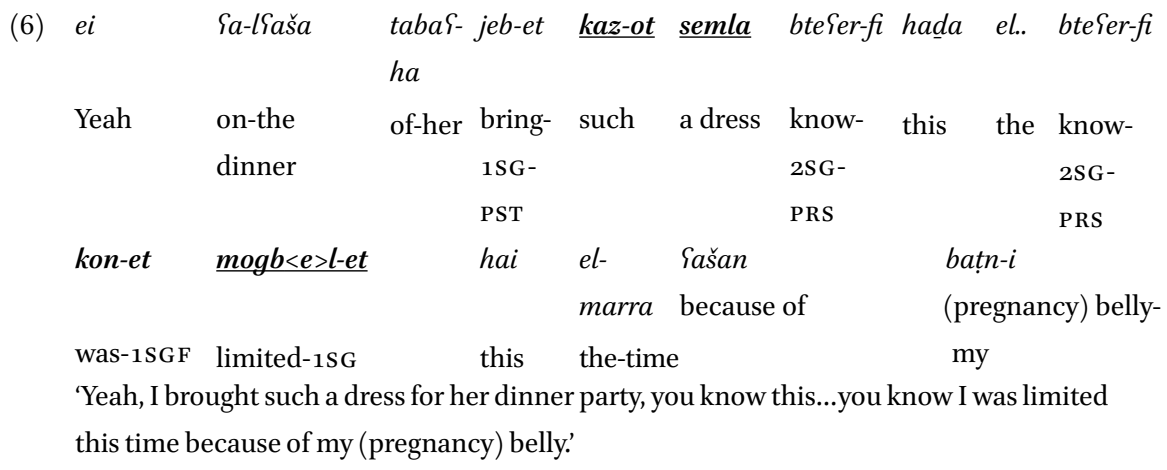


In (7) there is case in which the speaker uses a Hebrew verb and an adjective that agree with an Arabic pronoun in gender and number. In addition, the speaker uses an associative from Arabic tas-hun 'their' with a Hebrew noun Pofi 'character'.

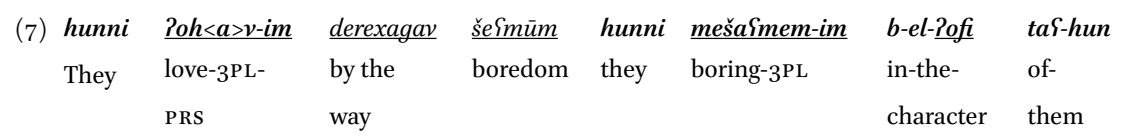

'They love, by the way, boredom, they are boring in their character.'

From the examples given above, it is evident that this level of codeswitching is part of the first phase of the Matrix Language turnover hypothesis. The first phase is reflected herein by the frequent Arabic/Hebrew codeswitching occurrences, while maintaining the role of the Matrix Language, Arabic, as the main provider of the system morphemes. Hebrew, which is the Embedded Language in this data set, provides content morphemes and Embedded Language islands that fit into the Matrix Language Frame model, thus maintaining its role as an Embedded Language. Table 3 shows the total number of the sampled CPs, as well as morphemes coming from both languages recorded in the present data sets (2017).

In the 1993 version of the Matrix Language Frame model, Myers-Scotton presented one of the principles defining the Matrix Language as being the source of more morphemes in a given discourse sample. However, in her later version (1997), she completely rejected that claim and it no longer appeared in any of her publications ever since. The data presented in table 3 , however, explicitly show that Israeli Hebrew is the source of more morphemes in the present sample. That obviously does not define Israeli Hebrew as the Matrix Language, but it definitely adds ambiguity and raises questions about its evident dominance and undermines the role of Arabic as a matrix Language. The data specifically show that Israeli Hebrew is the unmarked choice that quantitatively supplies more morphemes to the discourse than Palestinian Arabic, which appears

TABLE 3 Proportion of the languages in codeswitching (2017)

\begin{tabular}{|c|c|c|c|}
\hline Language & Palestinian Arabic & Israeli Hebrew & Mixed \\
\hline Total number of CPS & & & 1412 \\
\hline Total number of morphemes & 1267 & $145^{8}$ & 2725 \\
\hline Percentage & $46.5 \%$ & $53.5 \%$ & $100 \%$ \\
\hline
\end{tabular}


TABLE 4 Breakdown of the types of morphemes (2017)

\begin{tabular}{|c|c|c|c|c|}
\hline Language & $\begin{array}{l}\text { Palestinian } \\
\text { Arabic }\end{array}$ & $\begin{array}{l}\text { Israeli } \\
\text { Hebrew }\end{array}$ & Total & Examples \\
\hline $\begin{array}{l}\text { Content } \\
\text { morphemes }\end{array}$ & 571 & 854 & 1425 & $\begin{array}{l}\text { Eštaret/ARAB 'bought' } \\
\text { xanoot/НЕВ 'shop' }\end{array}$ \\
\hline $\begin{array}{l}\text { Early system } \\
\text { morphemes }\end{array}$ & 401 & 273 & 674 & $e l$-/АRAВ 'the' $z e /$ НЕ В 'this' \\
\hline $\begin{array}{l}\text { Bridge system } \\
\text { morphemes }\end{array}$ & 102 & 147 & 249 & $\begin{array}{l}\text { taS-hun/ARAB 'of them=their/ } \\
\text { theirs' šel-i/HEB 'of me=my/mine' }\end{array}$ \\
\hline $\begin{array}{l}\text { Outsider system } \\
\text { morphemes }\end{array}$ & 193 & 184 & 377 & $\begin{array}{l}\text {-li/DAT/ARAB 'for me' li/DAT/HEB } \\
\text { 'for me' }\end{array}$ \\
\hline
\end{tabular}

to be the marked choice in the present discourse sample. Table 4 , however, reinforces the dominance of Hebrew and shakes Arabic's role as the Matrix Language since Hebrew introduces a significant number of total system morphemes and more late system morphemes than Arabic. It is important to note that such system morphemes appear both independently and in Embedded Language islands. The introduction of the different system morphemes is a clear indication of a change in the morphosyntactic frame structuring the language. Table 4 shows the total number of the different types of the sampled morphemes used in each language, as well as the total number of the different morphemes coming from both languages recorded in the present data sets (2017).

\subsubsection{Examples of codeswitching and convergence (composite codeswitching)}

Examples (8) through (23) illustrate codeswitching and convergence to Israeli Hebrew in the present data sets (2017). All examples are of multilingual speakers fluent in both Palestinian Arabic and Israeli Hebrew, with Palestinian Arabic being their native tongue. Six of the participants are the same participants from the previous study conducted in 2000, thus the selected examples are taken mainly from their speech. The present data sets indicate that Hebrew plays a role in setting the morphosyntactic frame, which is a sign of a composite Matrix Language formation. Example (8) illustrates the Arabic determiner $\mathrm{el}$ 'the' as a frequently reoccurring early system morpheme followed by Hebrew content morphemes, e.g. xanoot and simla in this specific example. This mixed DP structure is the most common DP structure found in the data. In (8), there 
is also an instance in which the Hebrew content morpheme ve 'and', which is usually prefixed to Hebrew morphemes, is actually prefixed to an Arabic content morpheme eštar-et 'bought' while assimilating the $e$ from both languages. Example (8) also represents convergence of morphological realization pattern as the speaker puts an Arabic possessive phrase, that is, Arabic words, into a Hebrew pattern (lal-Sores tabaS SAnan/ARAB, laxatuna šel SAnan/HE B 'for the wedding of 'Anan') instead of the Arabic counterpart (la-Sores SAnan 'for 'Anan's wedding'). Hebrew-derived elements are underlined; other elements are from Arabic, morphemes under discussion or focal are in bold.

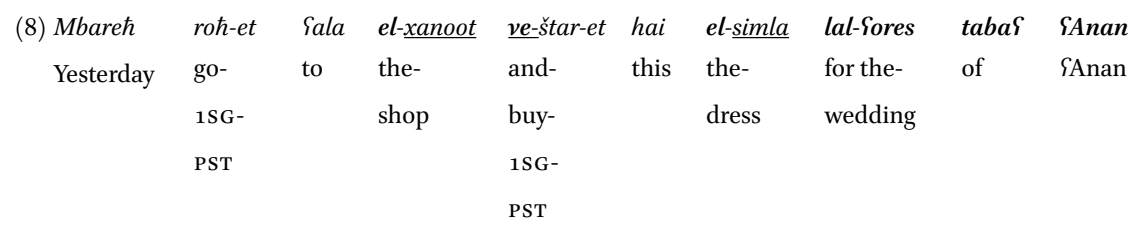

'Yesterday I went to the shop and bought this dress for 'Anan's wedding.'

In (9) there is an instance in which the Hebrew connector $v e$ 'and' is prefixed to an Arabic preposition $m I n$ 'from'. Other common switches show multiple instances in which Hebrew modifiers are used with Arabic elements.

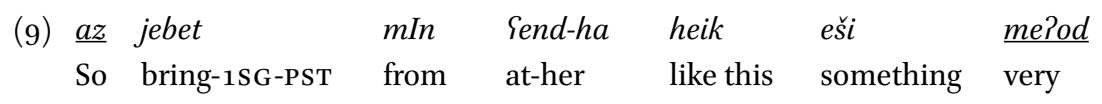

\begin{tabular}{|c|c|c|c|c|c|c|}
\hline$\frac{\text { tsamūd }}{\text { tight }}$ & $\begin{array}{l}m I n \\
\text { from }\end{array}$ & $\begin{array}{l}\text { hoan } \\
\text { here }\end{array}$ & $\begin{array}{l}\underline{\boldsymbol{v} e-m I n} \\
\text { and-from }\end{array}$ & $\begin{array}{l}\text { hoan } \\
\text { here }\end{array}$ & $\begin{array}{l}\text { byiji } \\
\text { come-3SG-PRs }\end{array}$ & $\frac{\underline{k a z e}}{\text { like this }}$ \\
\hline
\end{tabular}

'So I brought from her something like this, very tight from here and from here it comes navy blue like this.'

In (10) we have a case of a Druze lady who prefixes the Hebrew preposition be- 'in' to an Arabic article prefixed to a Hebrew noun (be-l-baSaya), in addition to using the Arabic grammatical rule of inflecting possessive adjective suffix to a verb while assimilating the consonant, and applies it upon a Hebrew verb (yetapel-i). In Hebrew, possessive dative pronouns occur as free morphemes and are not suffixed to verbs. The speaker inflects the possessive dative pronoun li 'for me' in Hebrew to a verb in Hebrew while assimilating the consonant l instead of using the Hebrew counterpart (yetapel li baba'aya 'treat my problem'). In Arabic it would bey\{alej-li (e)l-moškle. This example has two CPs with the Arabic complementizer Sašan 'so that' between them, and the second CP coming mainly from Hebrew. 
(10) roћet la-Send el-rofe Sašan yetapel-i be-l-baiaya

Go-1SG-PST to-at the-doctor so that treat-3SG-FUT-for me in-the-problem 'I went to the doctor so that he would treat my problem.'

In (11) we have a case of a Druze lady who uses a Hebrew negation marker lo 'not' with an Arabic verb hat-eit 'put'.

$\begin{array}{lllll}\text { (11) ana } & \underline{\mathbf{l o}} & \text { hat-eit } & \text { yotermedai } & \text { kesef } \\ \text { I } & \text { not } & \text { put-1SG-PST } & \text { too much } & \text { money } \\ & \text { 'I did not }[. . .] \text { put too much money.' }\end{array}$

In (12) there is an opposite case in which speaker B uses an Arabic negation marker miš 'not' with a Hebrew verb Sokevet 'follow'. In addition, speaker A inflects the Arabic pronominal clitic $b$ - to the Hebrew verb yagiš 'present', which is an indication of a composite. In Arabic the equivalent would be be-qadem, while in Hebrew it would be $m I$-giš.

(12a) qadei? kull wahad ke?elū akammen yom b-yagiš? How many? each one as if how many day PRS- present/3SG 'How many (days)? That is, how many days does each one present?'

$\begin{array}{lllllll}\text { (12b) ba-\{ref-eš } & \frac{\text { ta-Pemet }}{\text { 1SG-know-PRS-NEG }} & \text { ana } & \text { miš } & \underline{\text { Sokev-et }} & \text { wara } & \underline{\text { lo }} \\ \text { the-truth } & \text { I } & \text { not } & \text { follow-1SG-PRS } & \text { after } & \text { not }\end{array}$

$\begin{array}{lllllll}\text { yodas-at } & \underline{\text { neria }} & \underline{\underline{i}} & \text { yomein } & \text { fi-l-jomia } & \text { heik } & \text { eši } \\ \text { know- } & \text { seems } & \text { me } & \text { two days } & \text { In-the-week } & \text { like that } & \text { something } \\ \text { 1SGF- } & & & & & & \\ \text { PRS } & & & & & \end{array}$

'I don't know, the truth is I am not keeping track (of them), I don't know, I think two days a week, something like that.'

Example (13) shows a Hebrew bridge system morpheme-the relative pronoun še- 'that' being inflected with the Arabic pronoun neћna 'we'. In addition, the example shows the use of an Arabic late system morpheme-the pronominal clitic $m$-, which co-indexes the subject, inflected to the Hebrew verb $y$-axlif 'change', thus showing another indication of a composite. The Arabic counterpart would be m-In-yayyer while the correct Hebrew form would be n-axlif. 


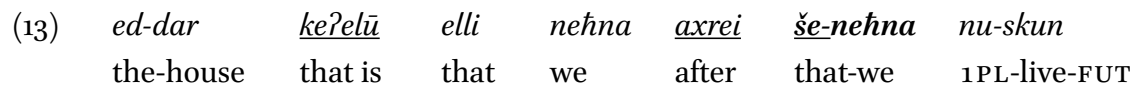

$\begin{array}{lll}\text { fi-ha } & \boldsymbol{m} \text {-n-axlif } & \text { el-rehūt } \\ \text { in-it } & \text { 1PL-FUT-change } & \text { the-furniture }\end{array}$

'The house, that is, that we, after, that we live in, we'll change the furniture.'

Example (14) shows an additional composite case in which a Hebrew negation morpheme ein 'not' is used with an Arabic pronoun. The speaker suffixes the Hebrew dative pronoun li 'for me' to the negation marker ein, a pattern which is generally used in Arabic, but not in Hebrew. In addition, an Arabic early system morpheme - the singular feminine demonstrative hai - is used with a Hebrew plural noun, thus the agreement rule for both languages is violated. However, the Arabic feminine demonstrative hai was used instead of the masculine demonstrative hada to show agreement with the gender of the Israeli noun. However, the Hebrew noun is inflected with the Arabic determiner $e$, which would be incorrect in Hebrew as it will not take a determiner in such cases.
(14) ana ein-li
I not have-for me
savlanut la
hai
el-šstuyot
'I do not have patience for this nonsense.'
this-SGF the nonsense-PLF
In Arabic the sentence would be:
'ana ma Yend-iš șaber la hada (e)l-habal'
I NEG have-not patience for DEM the-nonesense 'I do not have patience for this nonsense'
In Hebrew the equivalent would be:
'(ani) ein li savlanut la-štuyot ha-Pelo'
I not-have for-me patience for-nonesense DEM/PL 'I do not have patience for this nonsense'

Example (15) represents convergence of lexical-conceptual structure that is reflected in change in the semantic meaning of a verb. In this example we have a case in which the Arabic verb Sabar 'crossed' and the Israeli verb Savar 'passed/ crossed', that are phonetically similar, though not semantically so, is used to covey the meaning of the Hebrew counterpart. The use of this verb is based upon the Hebrew verb Savar, which conveys two meanings; both 'passed' and 'crossed'. The existing sense of the Arabic verb fabar, has nothing to do with the meaning of pass, like the Hebrew one does.

$\begin{array}{llll}\text { hōwi } & \text { Sabar } & \text { el-mevxan } & \underline{\text { be-hetstaynūt }} \\ \text { He } & \text { pass-3sG-PST } & \text { the-test } & \text { in-excellence }\end{array}$

'He passed the test excellently.' 
In (16) there is an example of inter-sentential codeswitching, in which speaker B, who produces a whole clause in Hebrew, uses a Hebrew early system morpheme-the singular masculine demonstrative $z e$ 'this' as it would have been used in Arabic, but not in Hebrew though. In Hebrew, the plural form ele 'these' would be used whereas in Arabic, it would be the singular form hai 'this'. Therefore, the singular element in $z e$ is co-indexed with the Arabic singular element of 'life' (hayā). In addition, late outsider system morphemes in the form of verb agreement are taken from Hebrew, as both speaker A and speaker B use them with Hebrew verbs, showing agreement with Arabic pronouns. Such usage is quite recurrent in the present data.

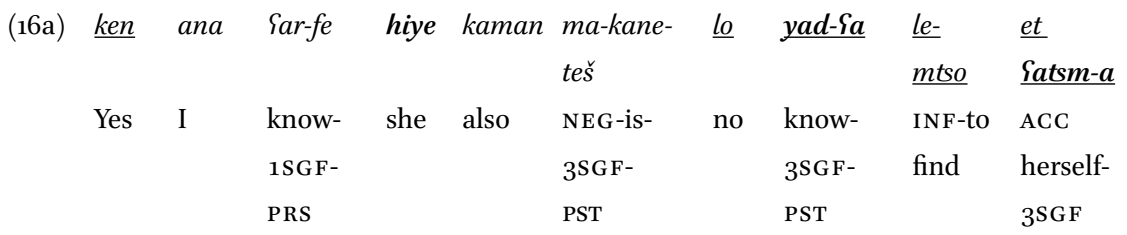

'Yes, I know, she also wasn't, didn't know (how) to find her way'

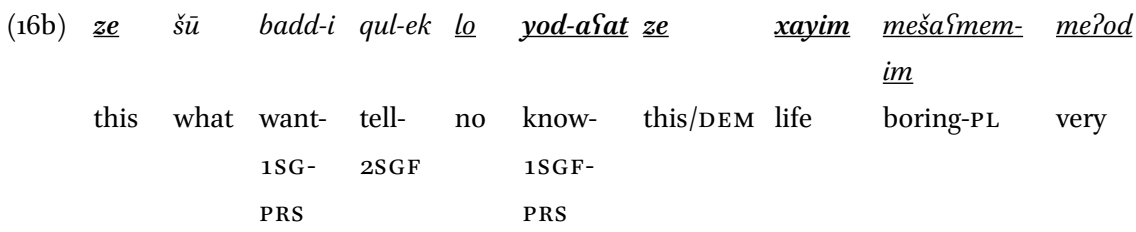

'This, what can I tell you, (I) don't know, this is a very boring life.'

Example (17) represents convergence of morphological realization patterns that is reflected in change in word order. In the example below, a Druze lady switches the word order of the Arabic adverb nebqa 'sometime' and the verb nrū 'go' to match it to the order in Hebrew. In Arabic it would be la-wein nanebqa nrüћ (to where we'll sometime go), whereas in Hebrew it would be le?an ne-lex mataišeho (to where we'll go sometime) 'where we'll go to sometime'. In addition, as in the previous example, the Hebrew outsider system morpheme -aSat is inflected with a Hebrew verb to show agreement with the speaker (ISGF).

$$
\begin{array}{lllll}
\underline{\text { lo }} & \text { yod-a a a t } & \text { la-wein } & \text { nan-rūh } & \text { nebqa } \\
\text { not } & \text { know-1SGF-PrS } & \text { to-where } & \text { 1 PL-FUT-go } & \text { sometime }
\end{array}
$$

'I don't know where we'll go to sometime.'

In (18) there is another example of change in word order, which is reflected in switching the order of a noun and an adjective. In this example the speaker uses the Hebrew adjective stam 'nonesense/stupid' with the Arabic noun šaylat 'things' while flipping the order between the two to match the Hebrew 
pattern. In Arabic it would be šayl-ät taf-ha (things stupid), while in Hebrew the order of the two would be stam dvar-im (stupid things) 'stupid things'. Also, the possessive Hebrew element $-i$ occurs as part of the Hebrew island me-bxenat- $i$ 'from my perspective' to agree with the Arabic pronoun ana 'I'. In addition, as in the previous examples, Hebrew outsider system morphemes are inflected with Hebrew verbs to show agreement with the Arabic pronoun (1SG).

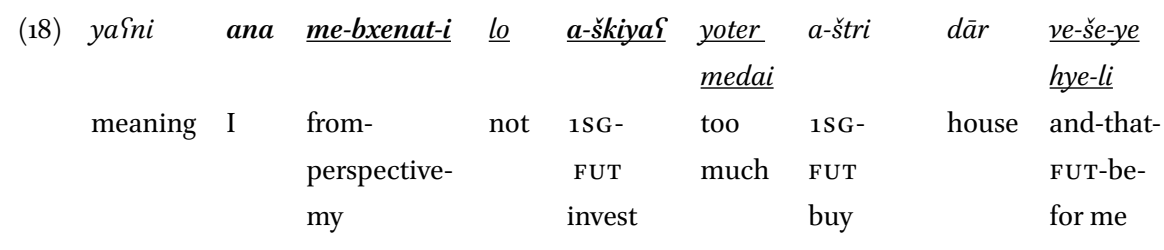

$\begin{array}{lllllll}\underline{\text { nexes }} & \text { wa-la } & \underline{\text { a-škeyaf }} & \text { Sala } & \underline{\text { stam }} & \text { šayl-āt } & \text { btefer-fi } \\ \text { asset } & \text { and-not } & \begin{array}{l}\text { 1SG-FUT } \\ \text { invest }\end{array} & \text { on } & \text { stupid } & \text { things } & \text { know-PRS-2SGF }\end{array}$

'That means, from my own perspective, I will not invest too much, I will buy a house so that I will have an asset and I will not invest (money) on stupid things, you know.'

In (19) there is a case in which the quantifier kol-am 'all of them', which is an outsider late system morpheme that must look outside its verb for information about its form, is used in Hebrew instead of its Arabic equivalent kull-hun or kull-ayat-(h)un. Also, as in the previous examples, a Hebrew outsider system morpheme is inflected with a Hebrew verb to show agreement with the Arabic pronoun (1SG).

$\begin{array}{cllllcll}\text { (19) hunni } & \underline{\text { kol-am }} & \text { rah-u } & \text { Sal-al-xatuna } & \text { ana } & \text { lo } & \text { rats-iti } & \text { a-ruh la-yad } \\ \text { They } & \text { all-of } & \text { go-3PL } & \text { to-the- } & \text { I } & \text { not want-1SG } & \text { INF/to- to- } \\ & \text { them } & \text { PST } & \text { wedding } & & \text { PST } & \text { go } & \text { there }\end{array}$

'All of them went to the wedding; I didn't want to go there.'

Note that in (20) there is a case in which another outsider system morpheme is taken from Hebrew rather than Arabic, this time it is the complementizer bešvil-a 'for her', used instead of its Arabic counterpart Sašan-ha. The comple-

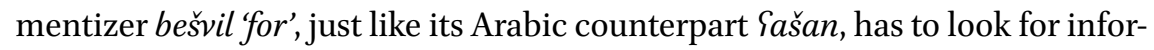
mation outside of its verb to shape its form. It is co-indexed with Eman (3SGF). Here again, as in the previous examples, a Hebrew outsider system morpheme is inflected with a Hebrew verb to show agreement with the Arabic pronoun (3SGF). 
(20a) ken w-keef Eman me-stader-et yad mas kullel-laxats w-el-hai? Yes and-how Eman PRS- manage-3SGF there with all the pressure and-the-this? 'Yes, and how is Eman managing there with all the pressure and such?'

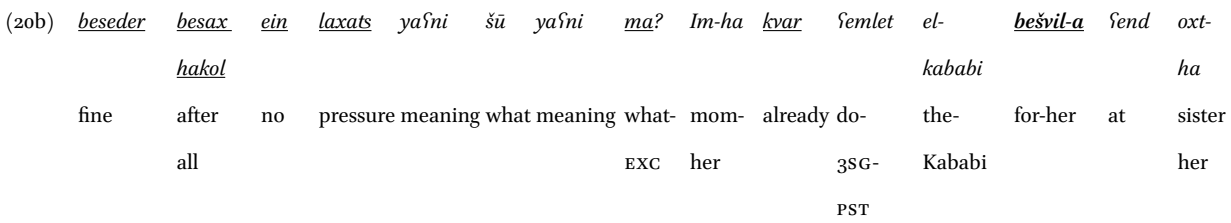

'Fine, after all there is no pressure, I mean, what for? Her mom had already done the Kababi (type of food) for her at her sister's.'

Interestingly, in (21) the Hebrew preposition le 'to' is prefixed to the Arabic proper name elquds, where in Arabic the equivalent $\{a l a$ is used interchangeably with the inflected form $\{a$-, thus 'to Jerusalem' would be Sala (e)lquds/ fa-lquds in this sentence, whereas in Hebrew it would be le-yerušalayim. It is noteworthy that a phonetically similar preposition exists in Arabic la- 'to/for'. Such a similarity may pose some confusion regarding the origin of the morpheme. However, the Arabic preposition $l a$ is not used for places but for people and things. For example: astetet-ha la-Sanan 'I gave it to 'Anan'. This shift to Hebrew, the 'old' Embedded language, not only violates the Uniform Structure Principle which gives preference to Matrix Language grammatical elements, but also illustrates a turnover of the system morpheme principle of the Matrix Language Frame. Here again, as in the previous examples, a Hebrew outsider system morpheme is inflected with a Hebrew verb to show agreement with the Arabic pronoun $(2 \mathrm{PL})$. It is interesting to note that although the Hebrew VP tafvir-u 'move-2PL/FUT' is elected over the Arabic counterpart tonoql-u, it is applied upon an Arabic pattern, since in Hebrew the correct form of the verb in such a sentence would be le-hasvir 'to move'.
$(21)$
badk-o
want-2PL/PRS
tafvir-u
et zeh
$\underline{\text { le-lquds? }}$
'Do you want to move this to Jerusalem?'
ACC this to-Jerusalem

In (22) there is a case in which the speaker uses a bridge late system morpheme from Hebrew šel 'of' with nouns and determiners from Arabic. šel is an associative marker that shows agreement in both gender and number. In this example šel- $i$ is co-indexed with first person (me) and šel- $x a$ is co-indexed with second person (you). This example also contradicts Myers-Scotton's (1993) principle 
that the system morphemes coming from the Embedded Language must come in the form of embedded language islands, thus showing another indication that there is a case of composite Matrix Language formation.

(22) hada el-finjan $\begin{aligned} & \text { sel-i } \\ & \text { this hadak the cup of-me that }\end{aligned}$
'This cup is mine, that one is yours.'

In (23) a Druze male uses a Hebrew auxiliary for a verb in the future in Arabic. In addition, a Hebrew outsider system morpheme is inflected with a Hebrew verb to show agreement with the Arabic pronoun (2SGF).

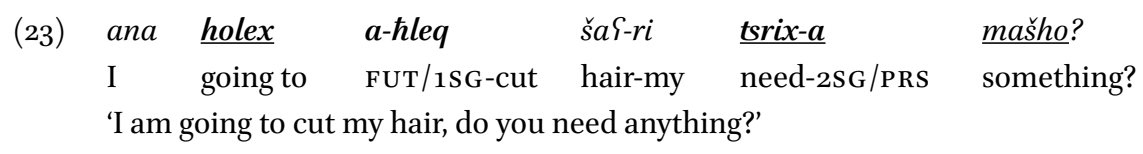

The above examples and tables indicate that there is a case of composite matrix language formation of Arabic and Hebrew. This composite conforms to stage II of the Matrix Language Turnover hypothesis. It is evident from the examples that both languages play the role of setting the morphosyntactic frame. There is an increase in the Hebrew lexical items and system morphemes are realized also in Hebrew, the previous embedded language, mainly in conjunction with content morphemes drawn from it as well. This significant introduction of Hebrew system morphemes appearing both independently and in embedded language islands shows a breakdown of the role of Arabic as the sole basis of the Matrix Language frame and a formation of a new, composite matrix language. As can be seen in the examples above, the composite language includes Lexical-conceptual and morphological realization structures coming from both languages Arabic and Hebrew. The morpheme order similarity between Arabic and Hebrew makes it hard to categorize this as belonging to either language, thus there are few cases in which it is mentioned. For the reasons mentioned above and the fact that the turnover does not go to full completion but is arrested at some point, we have a case of split language formation.

'Palebrew' - a new split language

The data indicate a split language formation as there is a Matrix Language turnover underway which is arrested and does not go to full completion. It is 
evident from the examples that Arabic and Hebrew do not entirely change in Matrix Language dominance, but stop through the process to form a composite Matrix Language that is a combination of both languages. The turnover to Hebrew was arrested to the point of having extensive Hebrew morphosyntactic elements, though not to a complete shift. According to the Matrix Language turnover hypothesis and the definitions of split languages, here lies a case of a split language formation. This is reflected in the splits not only in features, but in systems of features as well, such as the split in system morphemes and in late system morphemes as well, with the Hebrew introduction of both bridges and outsiders. This illustrates a split in the morphosyntactic frame itself. Since this split language includes morphosyntactic elements from both Israeli Hebrew and Palestinian Arabic, I shall call it 'Palebrew' (Palestinian + Hebrew). I do not call it 'Israeli Druze Arabic' due to the fact that it might be used by other individuals from the Arabic speaking community in Israel who are not Druze. I also do not call it Arabrew (Arabic + Hebrew) in order to distinguish it from the "variety" that some are trying to ascribe to the language that is spoken by Palestinians and the general Arab citizens of Israel, which is characterized by borrowings from Hebrew and classical codeswitching. (cf. Hawker, 2018).

It is noteworthy that the Israeli Arab citizens code switch as well, however, their codeswitching behaviour conforms to the classic type (Abu Elhija, 2017; Hawker, 2018). Codeswitching among Arabs who live in mixed cities with a Jewish majority and Bedouins who voluntarily serve in the Israeli army is much more intense than that of the rest of the Arab citizens (Christians and Muslims from the North and the Triangle region). However, codeswitching features of the majority of Arabs in mixed cities and the Bedouins also conform to the classic type since they exhibit mainly inter sentential switches and borrowings. The variety that is used by Druze speakers exhibits much more intense codeswitching and mixing of morphosyntactic features and conforms to the composite type that results in the split variety coined herein as 'Palebrew'.

The main structural features that 'Palebrew' includes are: (I) Hebrew and Arabic nouns both occur frequently and indistinctively; (II) Verbs come mainly from Hebrew; (III) Arabic definite articles inflected to both Arabic and Hebrew nouns; however, the mixed DP (an Arabic determiner inflected with a Hebrew noun) is the most common DP structure; (IV) Hebrew definite article inflected solely to Hebrew nouns; (v) Hebrew possessive adjectives are used, agreeing in gender and number with both Arabic and Hebrew nouns; (VI) Arabic possessive adjectives are used, agreeing in gender and number with both Hebrew and Arabic nouns; (VII) Hebrew prepositions are used with both Arabic and Hebrew elements; (VIII) Arabic prepositions are used with both Hebrew and Arabic elements; (IX) Hebrew adjectives that agree in gender 
and number are used with both Arabic and Hebrew nouns; (x) Arabic adjectives that agree in gender and number are used with both Hebrew and Arabic nouns; (XI) Hebrew demonstratives that agree in gender and number are used with both Arabic and Hebrew nouns; (XII) Arabic demonstratives that agree in gender and number are used with both Hebrew and Arabic nouns; (XIII) Adverbs come from both languages; (XIV) Quantifiers that do not agree in gender and number come mainly from Hebrew; (Xv) Quantifiers that agree in gender and number come from both languages; (XVI) Numerals come mainly from Hebrew; (XVII) Discourse markers come mainly from Hebrew.

\section{Conclusions}

The different native Arabic speaking communities in Israel code-switch to varying degrees of intensity. The Arab citizens who reside in mixed cities with a Jewish majority and the Bedouins of the north who voluntarily serve in the Israeli army share much more codeswitching features in their speech than the rest of the Muslims and Christians in Israel. However, codeswitching behaviour of the majority of Arabs in mixed cities and the Bedouins conforms to the classic type since it is characterized mainly by inter sentential switches and borrowings that do not cause major language change. The language of the Druze community in Israel, however, appears to be undergoing a process of language change. This change is reflected in the extensive intra-sentential and word-internal codeswitching between Arabic and Hebrew that has brought about convergence toward Hebrew and a composite, split language formation.

This split language formation can be explained under the Matrix Language turnover hypothesis. Codeswitching between both languages started at phase I of the hypothesis, which is reflected in frequent intra-clausal codeswitching occurrences, as well as core borrowings and lexicalization of embedded language structures in the matrix language. Along the path, a composite language is formed, carrying morphosyntactic elements of both languages in contact, the previous Matrix Language (Arabic) and the former Embedded Language (Hebrew). The Arabic/Hebrew codeswitching data herein indicate that over the years, convergence to Hebrew has brought about significant instances of Hebrew system morphemes brought into Arabic. The system morphemes introduced from Hebrew include all three types of system morphemes as outlined by the 4-M model: early system morphemes, and two kinds of late system morphemes, namely bridge system morphemes and outsider system morphemes. Since the turnover into Hebrew did not go to completion but stopped "along the way", it was a clear sign of a split language formation. Since both 
Palestinian Arabic and Israeli Hebrew set the morphosyntactic frame of this composite language, we can call this new split language 'Palebrew'.

Finally, identity factors and language attitudes are possible motivating features for such composite split language formation. In the case of the Druze community in Israel, such factors can play a prominent role in its language change. As the Israeli Druze people are "sandwiched" between the Arabs and Jews, they tend to seek distinctness through their language by forming a new, distinct speech that differs from that of both groups. Such distinct speech is reflected in convergence toward Hebrew and the extensive use of Hebrew lexemes and morphosyntactic structures and up to the point of composite split language formation. By forming this split language, not only do they distinguish themselves from both groups, but also emphasize their distinctness. It is also the case that since the Israeli Druze community generally holds Arabic in lower regard in comparison to Hebrew (Isleem, 2016), it decreases the feasibility of maintaining it and increases the likelihood of either creating a new mixed language, which is the case here, or getting to phase III of the Matrix Language turnover hypothesis, which is characterized by a complete matrix language turnover, hence a complete shift into Hebrew. At the same time, however, by not having a complete shift to Hebrew, they maintain a separate identity linking back to their historical roots.

\section{Acknowledgements}

I would like to express my immense gratitude to Professor Carol Myers-Scotton for her insightful comments on an earlier version of the manuscript. I am also grateful to Professor Ghil'ad Zuckermann and Professor Rob Amery for their comments and support during the course of this research.

\section{References}

Abu Elhija, Duaa. 2017. Hebrew Loanwords in the Palestinian Israeli Variety of Arabic (Facebook Data).Journal of Language Contact 10(3): 422-449.

Amara, Muhammad. 2010. Allugha El'arabiyya fi Israeel: Siyaqat wa-tahadiyat (Arabic Language in Israel: Contexts and Challenges). Nazareth: Dar Al-Huda and Dirasat, Amman: Dar Al-Fiker.

Amara, Muhammad. 2017. Arabic in Israel: Language, Identity and Conflict. Milton: Routledge.

Amara, Muhammad and Schnell, Izhak. 2004. Identity Repertoires among Arabs in Israel. Israel Journal of Ethics and Migration Studies 30: 175-193. 
Auer, Peter and Carol M. Eastman. 2010. Code-Switching. In Jaspers, Jürgen, Jef Verschueren, and Jan-Ola Östman (eds.), Society and Language Use, 84-112. Amsterdam: Benjamins.

Bakker, Peter. 1997. A Language of Our Own: The Genesis of Michif, the Mixed Cree-French Language of the Canadian Métis. Cary: Oxford University Press.

CBS. 2017: http://www.cbs.gov.il/reader/newhodaot/hodaa_template.html?hodaa= 201711106

Firro, Kais M. 2001. Reshaping Druze Particularism in Israel. Journal of Palestine Studies, 30(3): 40-53.

Fuller, Janet M. 1996. When Cultural Maintenance Means Linguistic Convergence: Pennsylvania German Evidence for the Matrix Language Turnover Hypothesis. Language in Society 25(4): 493-514.

Halabi, Rabah. 2006. Izrakhim Shave Khuvot: Zihot Druzit Vehamedina Hayehudit: (Citizens equal in duties: Druze identity and the Jewish state). Tel-Aviv: Hakibbutz Hame?ukhad.

Hawker, Nancy. 2018. The mirage of 'Arabrew': Ideologies for understanding ArabicHebrew contact. Language in Society 47(2): 219-244.

Henkin, Roni. 2013. Arabic, Hebrew loanwords in: Modern Period. In Geoffrey Khan, Shmuel Bolozky, Steven Fassberg, Gary A. Rendsburg, Aaron D. Rubin, Ora R. Schwarzwald and Tamar Zewi (eds.), Encyclopedia of Hebrew Language and Linguistics, 155-161. Leiden: Brill.

Isleem, Martin. 2016. Arabic-Hebrew Codeswitching: The Case of the Druze Community in Israel. International Journal of Applied Linguistics, 26(2): 228-244.

Jacob, M. Landau. 1993. The Arab Minority in Israel, 1967-1991: Political Aspects. Oxford: Oxford University Press.

Jake, Janice L. and Carol Myers-Scotton. 2009. Which Language? Participation Potentials across Lexical Categories in Codeswitching. In Isurin, Ludmila, Donald Winford and Kees de Bot. (eds.), Multidisciplinary Approaches to Code Switching, 207-242. Amsterdam: Benjamins.

Mar'i, Amara. 2013. Walla Beseder: A Linguistic Profile of the Israeli Arabs. Jerusalem: Keter.

Matras, Yaron. 2009. Language Contact. Cambridge: Cambridge University Press.

Mous, Maarten. 2003. Making of a Mixed Language: The Case of Ma'a/Mbugu. Amsterdam, Netherlands: Benjamins.

Myers-Scotton, Carol. 1997. Duelling Languages: Grammatical Structure in Codeswitching. Oxford: Clarendon Press.

Myers-Scotton, Carol. 1998. A Way to Dusty Death: The Matrix Language Turnover Hypothesis. In Lenore and Lindsay Whaley (eds.), Endangered Languages: Language Loss and Community Response, 289-316. Cambridge: Cambridge Univ. Press.

Myers-Scotton, Carol. 2002. Contact Linguistics: Bilingual Encounters and Grammatical Outcomes. Oxford: Oxford University Press. 
Myers-Scotton, Carol. 2003. What Lies Beneath: Split (Mixed) Languages as Contact Phenomena. In Yaron Matras and Peter Bakker (eds.), The Mixed Language Debate: Theoretical and Empirical Advances, 73-106. Berlin: Mouton de Gruyter.

Myers-Scotton, Carol. 2006. Multiple voices: Introduction to bilingualism. Malden, MA: Blackwell Publishers.

Myers-Scotton, Carol. 2008. Language Contact: Why Outsider System Morphemes Resist Transfer. Journal of Language Contact 2: 21-41.

Myers-Scotton, Carol. 2013. Paying attention to morpheme types: making borrowability more precise. In C. de Feral (ed.), In and out of Africa. Languages in question, 31-42. Louvain: Peeters.

Myers-Scotton, Carol and Janice L. Jake. 2001. Explaining Aspects of Codeswitching and Their Implications. In Janet Nicole (ed.), One Mind, Two Languages: Bilingual Language Processes, 84-116. Oxford: Blackwell.

Myers-Scotton, Carol and Janice L. Jake. 2009. A universal model of code-switching and bilingual language processing and production. In B. Bullock and A. Toribio (eds.), The Cambridge Handbook of Linguistic Code-switching, 336-357. Cambridge: Cambridge University Press.

Myers-Scotton, Carol and Janice, L. Jake. 2017. Revisiting the 4-M model: Codeswitching and morpheme election at abstract level. International Journal of Bilingualism $21(3): 340-366$.

Nisan, M. 2010. The Druze in Israel: Questions of Identity, Citizenship, and Patriotism. The Middle East Journal 64(4): 575-596.

Thomason, Sally. 1997. Contact languages: A Wider Perspective. Amsterdam: Benjamins.

Vakhtin, Nikolai. 1998. Copper Island Aleut: a case of language "resurrection". In Lenore and Lindsay Whaley (eds.), Endangered Languages: Language Loss and Community Response, 317-327. Cambridge: Cambridge Univ. Press.

Zuckermann, Ghil'ad. 2006. Complement Clause Types in Israeli. In Robert M. W. Dixon and Alexandra Y. Aikhenvald (eds.), Complementation: A Cross-Linguistic Typology, 72-92. Oxford: Oxford University Press.

Zuckermann, Ghil'ad. 2008. Israelit Safa Yafa (Israeli-A Beautiful Language). Tel-Aviv: Am Oved.

Zuckermann, Ghil'ad. 2009. Hybridity versus Revivability: Multiple Causation, Forms and Patterns. Journal of Language Contact (2): 40-67.

Zuckermann, Ghil'ad. 2010. Do Israelis Understand The Hebrew Bible? The Bible and Critical Theory 6(1): 6.1-6.7. 